\title{
Body proportions in children with Kabuki syndrome
}

Citation for published version (APA):

Penders, B., Schott, N., Gerver, W. J. M., \& Stumpel, C. T. R. M. (2016). Body proportions in children with Kabuki syndrome. American Journal of Medical Genetics Part A, 170(3), 610-614. https://doi.org/10.1002/ajmg.a.37467

Document status and date:

Published: 01/03/2016

DOI:

10.1002/ajmg.a.37467

Document Version:

Publisher's PDF, also known as Version of record

Document license:

Taverne

\section{Please check the document version of this publication:}

- A submitted manuscript is the version of the article upon submission and before peer-review. There can be important differences between the submitted version and the official published version of record.

People interested in the research are advised to contact the author for the final version of the publication, or visit the DOI to the publisher's website.

- The final author version and the galley proof are versions of the publication after peer review.

- The final published version features the final layout of the paper including the volume, issue and page numbers.

Link to publication

\footnotetext{
General rights rights.

- You may freely distribute the URL identifying the publication in the public portal. please follow below link for the End User Agreement:

www.umlib.nl/taverne-license

Take down policy

If you believe that this document breaches copyright please contact us at:

repository@maastrichtuniversity.nl

providing details and we will investigate your claim.
}

Copyright and moral rights for the publications made accessible in the public portal are retained by the authors and/or other copyright owners and it is a condition of accessing publications that users recognise and abide by the legal requirements associated with these

- Users may download and print one copy of any publication from the public portal for the purpose of private study or research.

- You may not further distribute the material or use it for any profit-making activity or commercial gain

If the publication is distributed under the terms of Article $25 \mathrm{fa}$ of the Dutch Copyright Act, indicated by the "Taverne" license above, 


\section{Next-generation decisions empowered by next-generation technology} When accuracy matters-reproductive genetic testing with Ion Torrent NGS solutions

Next-generation sequencing (NGS) technology is revolutionizing reproductive research with fast, accurate, and comprehensive detection of a broad spectrum of genetic variants found to cause inherited disorders.

Labs implementing NGS for inherited disease research are expanding the ability of the scientific community to identify and understand life-altering genetic variants.

How can you make an impact? Learn more about expanded carrier-screening research and preimplantation genetic testing with lon Torrent ${ }^{\mathrm{TM}}$ NGS technology including the lon GeneStudio'm S5 System.

- Sample-to-result workflows

- Intuitive data analysis

- Accessibility, regardless of technical or bioinformatics experience

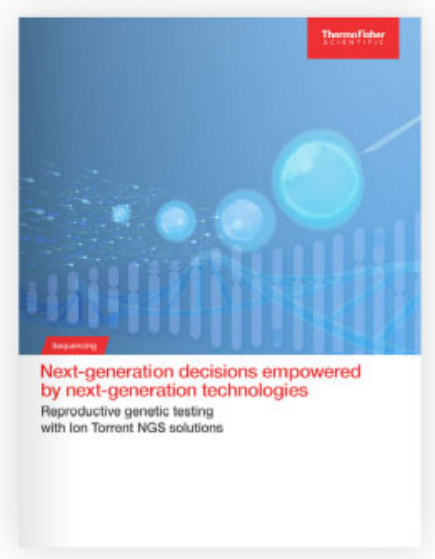

" $80 \%$ of parents with a child born with a recessive disorder are not aware of a family history of that condition." Learn more in this brochure. 


\title{
Body Proportions in Children with Kabuki Syndrome
}

\author{
Bas Penders, ${ }^{1 *}$ Nina Schott, ${ }^{1}$ Willem-Jan M. Gerver, ${ }^{1}$ and Constance T. R. M. Stumpel ${ }^{2}$ \\ ${ }^{1}$ Department of Paediatric Endocrinology Maastricht University Medical Centre (MUMC+), The Netherlands \\ ${ }^{2}$ Department of Clinical Genetics and School for Oncology \& Developmental Biology (GROW), Maastricht University, The Netherlands
}

Manuscript Received: 13 August 2015; Manuscript Accepted: 26 October 2015

Facial characteristics, short stature, and skeletal anomalies have been described for the clinical diagnosis of Kabuki Syndrome (KS) in children. However, no studies have investigated body proportions in KS. Knowledge of body proportions in KS may contribute to better insight into the growth pattern and characterization of this genetic disorder. Therefore we compared body proportions of children with KS to normally proportioned controls to investigate if atypical body proportions are part of this genetic disorder. This study was designed and conducted within the setting of the Maastricht University Medical Centre $(\mathrm{MUMC}+)$, the official Dutch expert center for Kabuki syndrome. We conducted a cross-sectional study in 32 children (11 children with KS and 21 controls). Body proportions were determined by means of photogrammetric anthropometry, measurements based on digital photography. Body proportions, quantified as body ratios, differ significantly in children with KS from normally proportioned children. Children with KS have larger heads and longer arms proportional to their trunks and have been found to have longer upper arms proportional to their tibia length and feet. Based on deviations in body proportions it was shown possible to discern children with KS from normally proportioned controls. $\odot 2015$ Wiley Periodicals, Inc.

Key words: Kabuki syndrome; body proportions; photogrammetric anthropometry; children

\section{INTRODUCTION}

Children with Kabuki syndrome (KS) are characterized by a distinct facial appearance, mild to moderate intellectual disability, postnatal growth retardation, skeletal anomalies, and unusual dermatoglyphic patterns [Niikawa et al., 1981]. Two genes have shown to be mutated in patients with KS, $55-80 \%$ present mutations in the MLL2/KMT2D gene and in $9-14 \%$ the KDM6A gene is mutated [ $\mathrm{Ng}$ et al., 2010; Lederer et al., 2012; Dentici et al., 2015].

The facial characteristics, which are used in the clinical diagnosis of KS, have been described extensively in recent literature, several studies also describe the presence of short stature and skeletal anomalies in KS [Niikawa et al., 1981; Wilson, 1998; Mhanni et al., 1999; Digilio et al., 2001; Shotelersuk et al., 2002; Schrander-

\section{How to Cite this Article:}

Penders B, Schott N, Gerver W-JM, Stumpel CTRM. 2016. Body proportions in children with kabuki syndrome.

Am J Med Genet Part A 170A:610-614.

Stumpel et al., 2005]. However, no studies have investigated body proportions in these children. Knowledge of body proportions in KS may contribute to better insight into the growth pattern and characterization of this genetic disorder. Therefore we performed a cross-sectional study to compare body proportions of children with KS to normally proportioned controls.

\section{METHODS}

This study was designed and conducted within the setting of the Maastricht University Medical Centre (MUMC+), the official Dutch expert center for Kabuki syndrome. We work in close collaboration with the Dutch Kabuki Network.

\section{Study Groups}

In total, 11 children, between 3 and 16 years old, visiting the expert center for Kabuki syndrome in the Maastricht University Medical Centre were included in this study. KS was confirmed in all participating children based on the presence of gene mutations in MLL2/KMT2D. No mutations in KDM6A were found. For the control group, 21 children between 2 and 14 years old, visiting the

Conflicts of interest: The authors have no conflicts of interest to disclose. Bas Penders and Nina Schott joint first authorship.

Willem-Jan M. Gerver and Constance T. R. M. Stumpe joint last authorship.

*Correspondence to:

Bas Penders, Maastricht University Medical Centre, Department of Paediatrics, P. Debyelaan 25, postbus 5800, NL-6202 AZ Maastricht.

E-mail: bas.penders@maastrichtuniversity.nl

Article first published online in Wiley Online Library

(wileyonlinelibrary.com): 9 November 2015

DOI 10.1002/ajmg.a.37467 
outpatient clinic of Endocrinology and Growth of the Maastricht University Medical Centre were included. These children were all growth hormone deficient and received adequate growth hormone therapy. These children were all proportioned normally according to the Dutch reference values [Gerver and de Bruin, 2011]. Before inclusion, all patients and/or their parents had given informed consent.

\section{Measurements}

In a previous study, we developed a new method for taking anthropometric measurements, using photogrammetric anthropometry. It was shown to be a fast, easy to use, validated method to take elaborate antropometric measurements of the whole body, especially body proportions [Penders et al., 2015]. Collected data used in this crosssectional study are digital photographs taken of the children in underwear. Photographs are taken in a frontal and lateral position and measurements on these photographs are performed using the photometry software Paediatric Morphometrics designed by our research group. Digital photographs were taken conform the photogrammetric method described previously [Penders et al., 2015]. Body proportions were determined according to the measurements of various anthropometric distances by selecting anatomical reference points in the photographs. These are the same reference points used in manual measurements [Gerver and de Bruin, 2011]. The measurements included: height $(\mathrm{H})$, biacromial width (Biac), biiliacum width (Biil), upper arm length (UA), lower arm length (LA), hand length (HA), tibia length (Tibl), and foot length(FO). Additionally, head length $(\mathrm{Hl})$ was determined on the photograph as the height difference between the top of the head and the chin. Trunk length ( $\mathrm{Trl}$ ) was determined as the height difference between biacromial width and biiliacum width. Arm length (ARM) was determined as the summation of upper arm length, lower arm length, and hand length.

\section{Statistical Analysis}

All data were exported to IBM SPSS Statistics for Windows version 20.0 for statistical analysis. Shapiro-Wilk tests were performed for all measurements to test for normality. Comparison of different groups was done using independent student $t$-test, Mann Whitney U test or Fisher's exact as appropriate.

\section{RESULTS}

\section{Characteristics of the Study Participants}

A total of 32 children were enrolled in this study (11 children and 21 controls). Both groups were comparable regarding age and gender. Significant differences between groups were seen in several proportional measurements. All characteristics are presented in Table I.

The eight ratios $\mathrm{Hl} / \mathrm{H}, \mathrm{Trl} / \mathrm{H}, \mathrm{Hl} / \mathrm{Trl}, \mathrm{ARM} / \mathrm{Trl}, \mathrm{UA} / \mathrm{Tibl}, \mathrm{UA} / \mathrm{FO}$, $\mathrm{Tibl} / \mathrm{H}$, and FO/Tibl show significant differences between children with KS and normally proportioned children. When presented for age, the ratios Hl/Trl, ARM/Trl, UA/Tibl and UA/FO show distinct distribution differences. These distributions are presented in Figures 1-4 where the black dots represent the control group and the white dots represent the KS group.

\section{DISCUSSION}

To our best knowledge, this is the first report on body proportions in children with Kabuki syndrome. We used photogrammetric

\begin{tabular}{|c|c|c|c|}
\hline & Children with KS & Controls & $P$-value \\
\hline $\mathrm{N}$ & 11 & 21 & \\
\hline Gender $\mathrm{m} / \mathrm{v}[\%]$ & $58 / 42$ & $76 / 24$ & 0.433 \\
\hline Age (range) & $\begin{array}{c}8.3 \pm 3.4 \\
(3.7-16.0)\end{array}$ & $\begin{array}{l}10.2 \pm 3.3 \\
(2.6-14.8)\end{array}$ & 0.138 \\
\hline $\mathrm{HI} / \mathrm{H}$ & $0.20 \pm 0.03$ & $0.17 \pm 0.02$ & $<0.001$ \\
\hline $\mathrm{HI} / \mathrm{Trl}$ & $0.82 \pm 0.07$ & $0.55 \pm 0.06$ & $<0.001$ \\
\hline Biac/Biil & $1.25 \pm 0.12$ & $1.22 \pm 0.07$ & 0.363 \\
\hline $\mathrm{Biac} / \mathrm{H}$ & $0.22[0.20-0.23]$ & $0.23[0.22-0.23]$ & 0.457 \\
\hline $\mathrm{Biil} / \mathrm{H}$ & $0.17[0.16-0.20]$ & $0.18[0.18-0.19]$ & 0.123 \\
\hline $\mathrm{Trl} / \mathrm{H}$ & $0.25[0.23-0.26]$ & $0.30[0.29-0.32]$ & $<0.001$ \\
\hline ARM/H & $0.43[0.38-0.45]$ & $0.42[0.41-0.43]$ & 0.289 \\
\hline ARM/Trl & $1.76[1.68-1.88]$ & $1.35[1.31-1.47]$ & $<0.001$ \\
\hline UA/LA & $1.24 \pm 0.16$ & $1.21 \pm 0.07$ & 0.565 \\
\hline UA/Tibl & $0.97 \pm 0.06$ & $0.76 \pm 0.05$ & $<0.001$ \\
\hline UA/FO & $1.30 \pm 0.09$ & $1.09 \pm 0.09$ & $<0.001$ \\
\hline Tibl/H & $0.19 \pm 0.02$ & $0.23 \pm 0.01$ & $<0.001$ \\
\hline $\mathrm{Tibl} / \mathrm{Trl}$ & $0.80[0.77-0.84]$ & $0.77[0.70-0.79]$ & 0.051 \\
\hline FO/Tibl & $0.75 \pm 0.07$ & $0.70 \pm 0.05$ & 0.027 \\
\hline
\end{tabular}




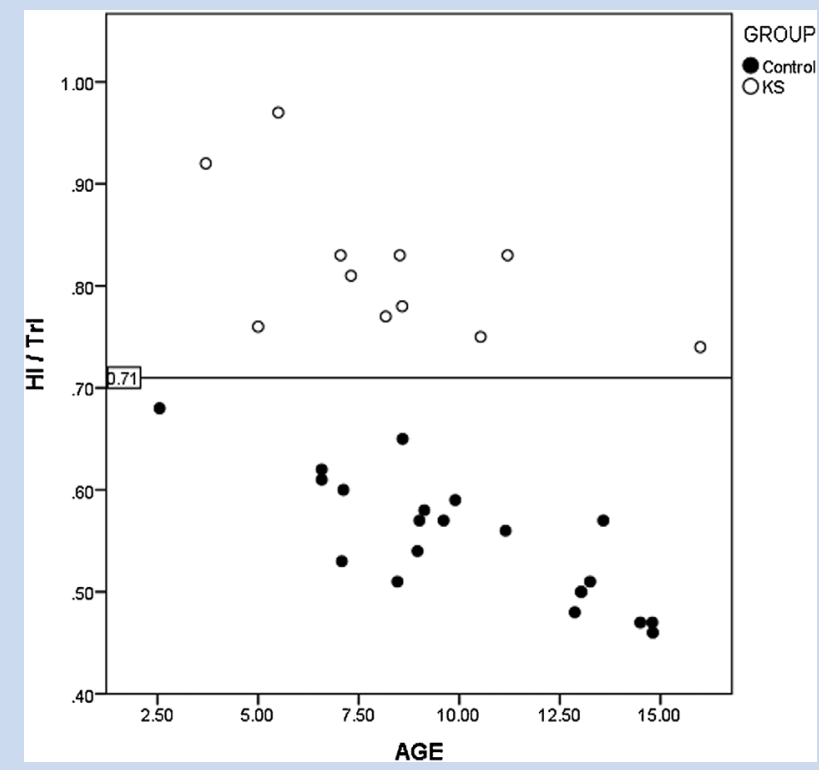

FIG. 1. HI/Trl distribution for age; HI, head length; Trl, trunk length.

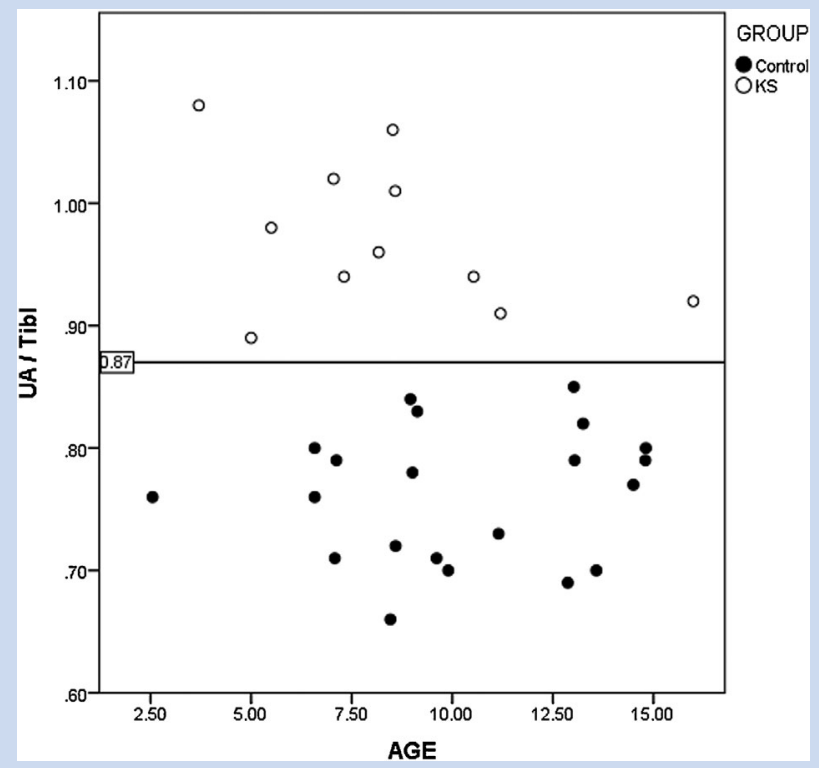

FIG. 3. UA/Tibl distribution for age UA, upper arm; Tibl, tibia length.

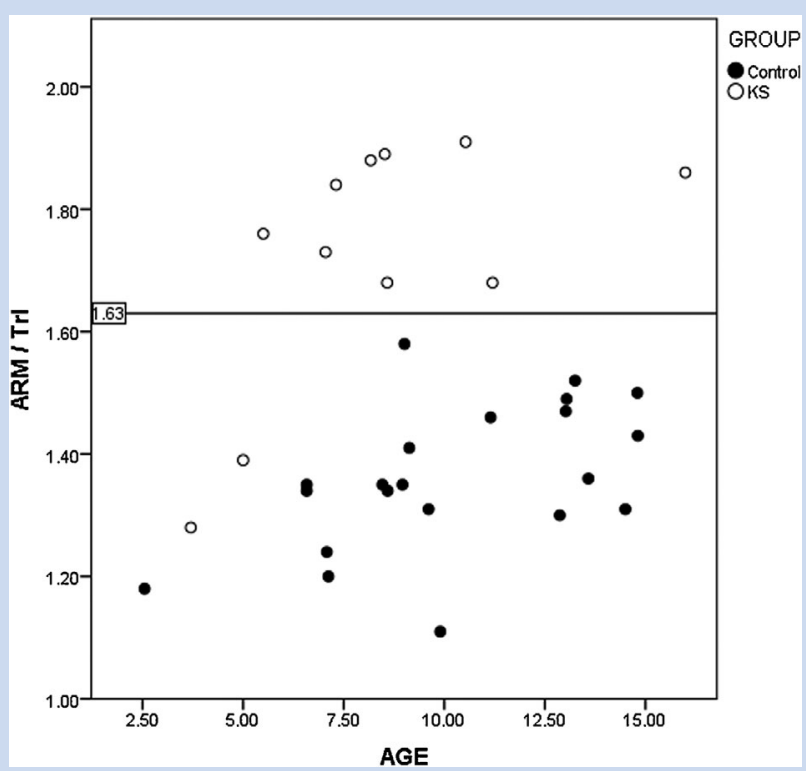

FIG. 2. ARM/Trl distribution for age ARM, arm length; Trl, trunk length.

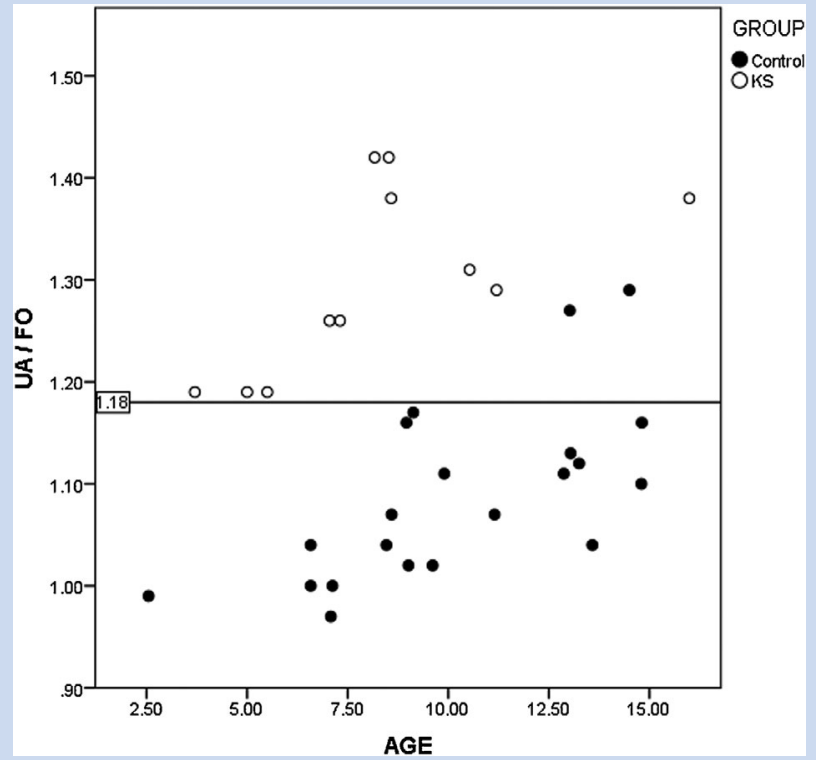

FIG. 4. UA/FO distribution for age UA, upper arm; FO, foot. anthropometry to estimate the body proportions of these children and compared the results to a reference group of normally proportioned children. We also used this method to determine if atypical body proportions are a characteristic feature in children with KS.

The ratios Hl/Trl, ARM/Trl, UA/Tibl, and UA/FO for age in children with KS clearly differentiate from the reference group.
These ratios show that children with KS have larger heads and longer arms proportional to their trunks compared to normally proportioned children. Additionally, children with KS have been found to have longer upper arms proportional to their tibia length and feet. These differences can be quantified as proportional cut-off values which are independent of age. In all children with KS a 
$\mathrm{Hl} / \mathrm{Trl}$ ratio $>0.71$ was found, opposed to the reference group which showed a Hl/Trl ratio $<0.71$. Similar results were found for ARM/Trl ( $>1.63$ for KS), UA/Tibl $(>0.87$ for KS) and UA/FO $(>1.18$ for KS). Based on these deviations in body proportions it was shown possible to discern children with KS from normally proportioned controls. Analysis of these body proportions can be done accurately with photogrammetric anthropometry, which is a fast, low-cost, and easy to perform method.

In other conditions where short stature and skeletal anomalies are present, such as idiopathic short stature (ISS), SHOX gene (short stature homeobox-containing gene) defects, and Turner syndrome (TS), more research has been done on body proportions. In an extensive study of Malaquias et al. abnormal body proportions were observed in $88 \%$ of the children with SHOX-defects, $48 \%$ of the females with TS and $16 \%$ of children considered ISS [Malaquias et al., 2013]. However, only Sitting height/Height ratio $(\mathrm{SH} / \mathrm{H})$ was investigated. In our study, it was not possible to accurately determine sitting height, neither manually, nor with the aid of photogrammetric anthropometry. Since children with KS often have difficulty with maintaining a certain pose for accurate manual measurement, sitting height was proven to be inaccurate. In a previous study we investigated if sitting height could be determined on a photograph, however this lead to imperfect results [Penders et al., 2015]. However, with the aid of photogrammetric anthropometry, we were able to examine other anthropometric ratios, that gave us an elaborate overview of the body proportions of these children.

It is known that in many skeletal dysplasias, growth of the legs, and arms is often more negatively affected than growth of the trunk [Hagenäs and Hertel, 2003]. Interestingly, we found that in children with KS arm length was proportionately longer compared to trunk length. No significant difference were found between groups for tibia length proportional to trunk length.

When SHOX gene defects are present, shortening of the extremities is a main cause of short stature. In these children, the arm span and leg length is significantly reduced in comparison to the height [Ross et al., 2001; Binder et al., 2003]. In children with KS we found no significant differences in arm length proportional to height compared to normally proportioned children, although tibia length was significantly shorter proportional to their height.

Body proportions in TS have between described in untreated girls with between 2-11 years of age. Since height is more affected in these children than other parts of the body, these girls have, on average, a relatively large trunk, large hands and feet, and relatively large biacromial width and biiliacum width proportional to their height [Sas et al., 1999]. In the children with KS we found that they had, on average, a relatively small trunk compared to normally proportioned controls. Also, we found no significant differences in biacromial width and biiliacum width proportional to height between the children with KS and the reference group.

Apart from $\mathrm{SH} / \mathrm{H}$ ratio, body proportions have not been elaborately described in children with idiopathic short stature. Therefore comparison of body proportions to the children with KS in this study is not yet possible.

In future studies we will compare body proportions in KS with other conditions in which short stature and skeletal anomalies are present. It will be interesting to determine if the proportional ratios presented in this study can also be used to differentiate various skeletal anomalies in children from each other.

\section{CONCLUSION}

To our best knowledge, this is the first report on body proportions in Kabuki syndrome. It is shown here that various body ratios in KS clearly deviate from normally proportioned children. The key differences in body proportions in KS are that these children have larger heads and longer arms proportional to their trunks and longer upper arms proportional to their tibia length and feet. Knowledge of these body proportions in KS is valuable, since it can strengthen the clinical diagnosis and provide the means to follow up on the body proportions during growth and development.

\section{ACKNOWLEDGMENTS}

The authors thank the children with Kabuki syndrome, their families, and the Dutch Kabuki Network for their collaboration.

\section{REFERENCES}

Binder G, Ranke MB, Martin DD. 2003. Auxology is a valuable instrument for the clinical diagnosis of SHOX haploinsufficiency in school-age children with unexplained short stature. J Clin Endocrinol Metab 88:4891-4896.

Dentici ML, Di Pede A, Lepri FR, Gnazzo M, Lombardi MH, Auriti C, Petrocchi S, Pisaneschi E, Bellacchio E, Capolino R, Braguglia A, Angioni A, Dotta A, Digilio MC, Dallapiccola B. 2015. Kabuki syndrome: Clinical and molecular diagnosis in the first year of life. Arch Dis Child 100: $158-164$.

Digilio MC, Marino B, Toscano A, Giannotti A, Dallapiccola B. 2001. Congenital heart defects in Kabuki syndrome. Am J Med Genet 100:269-274.

Gerver WJM, de Bruin R. 2011. Paediatric Morphometrics: A Reference Manual. Universitaire Pers Maastricht, Maastricht, The Netherlands.

Hagenäs L, Hertel T. 2003. Skeletal dysplasia, growth hormone treatment and body proportion: Comparison with other syndromic and nonsyndromic short children. Horm Res 60:65-70.

Lederer D, Grisart B, Digilio MC, Benoit V, Crespin M, Ghariani SC, Maystadt I, Dallapiccola B, Verellen-Dumoulin C. 2012. Deletion of KDM6A, a histone demethylase interacting with MLL2, in three patients with Kabuki syndrome. Am J Hum Genet 90:119-124.

Malaquias AC, Scalco RC, Fontenele EGP, Costalonga EF, Baldin AD, Braz AF, Funari MFA, Nishi MY, Guerra-Junior G, Mendonca BB, Arnhold IJP, Jorge AAL. 2013. The sitting height/height ratio for age in healthy and short individuals and its potential role in selecting short children for SHOX analysis. Horm Res Paediatr 80:449-456.

Mhanni AA, Cross HG, Chudley AE. 1999. Kabuki syndrome: Description of dental findings in eight patients. Clin Genet 56:154-157.

Ng SB, Bigham AW, Buckingham KJ, Hannibal MC, McMillin MJ, Gildersleeve HI, Beck AE, Tabor HK, Cooper GM, Mefford HC, Lee C, Turner EH, Smith JD, Rieder MJ, Yoshiura K, Matsumoto N, Ohta T, Niikawa N, Nickerson DA, Bamshad MJ, Shendure J. 2010. Exome sequencing identifies MLL2 mutations as a cause of Kabuki syndrome. Nat Genet 42:790-793. 
Niikawa N, Matsuura N, Fukushima Y, Ohsawa T, Kajii T. 1981. Kabuki make-up syndrome: A syndrome of mental retardation, unusual facies, large and protruding ears, and postnatal growth deficiency. J Pediatr 99:565-569.

Penders B, Brecheisen R, Gerver A, van Zonneveld G, Gerver W-J. 2015. Validating Paediatric Morphometrics: Body proportion measurement using photogrammetric anthropometry. J Pediatr Endocrinol Metab.

Ross JL, Scott C Jr, Marttila P, Kowal K, Nass A, Papenhausen P, Abboudi J, Osterman L, Kushner H, Carter P, Ezaki M, Elder F, Wei F, Chen H, Zinn AR. 2001. Phenotypes Associated with SHOX Deficiency. J Clin Endocrinol Metab 86:5674-5680.

Sas TC, Gerver WJ, de Bruin R, Stijnen T, de Muinck Keizer-Schrama SM, Cole TJ, van Teunenbroek A, Drop SL. 1999. Body proportions during long-term growth hormone treatment in girls with Turner syndrome participating in a randomized dose-response trial. J Clin Endocrinol Metab 84:4622-4628.

Schrander-Stumpel CT, Spruyt L, Curfs LM, Defloor T, Schrander JJ. 2005. Kabuki syndrome: Clinical data in 20 patients, literature review, and further guidelines for preventive management. Amer J Med Genet A 132A:234-243.

Shotelersuk V, Punyashthiti R, Srivuthana S, Wacharasindhu S. 2002. Kabuki syndrome: Report of six Thai children and further phenotypic and genetic delineation. Amer J Med Genet 110:384-390.

Wilson GN. 1998. Thirteen cases of Niikawa-Kuroki syndrome: Report and review with emphasis on medical complications and preventive management. Amer J Med Genet 79:112-120. 